\title{
Genetics of longevity
}

\author{
V Mari $^{1 *}$, S Dato $^{2}$ \\ From de Senectute: Age and Health Forum \\ Catanzaro, Italy. 5-7 December 2009
}

Epidemiological and family-based studies in different populations underlined the existence of a genetic component in human longevity.

Studies on families of centenarians demonstrated that parents, siblings and offspring of long-lived subjects have a significant survival advantage. In particular, the survival curve of siblings of centenarians is significantly higher than that people belonging to the same birth cohort. Moreover, siblings of centenarians have a lower risk of suffering from major age-related diseases, such as cardiovascular diseases, diabetes and cancer, when compared to appropriate selected controls from the same population. Indeed, studies on the concordance of the age of death in twins demonstrated a higher correlation in monozygotic than dyzigotic twins and suggested that approximately $25 \%$ of the variation in adult lifespan is caused by genetic differences between individuals. It was also demonstrated that the genetic component affecting longevity increases at advanced ages and it is generally stronger in males than in females. Furthermore, a positive correlation between population homozygosity and longevity was suggested, confirming the relevance of genetic differences between individuals for the susceptibility to a long lifespan.

Identifying genes that affect human longevity can provide information about the molecular mechanisms involved in the aging process and shed light on the heterogeneity of the aging phenotype. Studies on experimental models suggest that caloric restriction improves age-related health and slow the aging process by limiting energy intake. Furthermore, in animal models specific alterations in single genes (age-1, daf2, sir2, methusela, p66) can dramatically extend or decrease lifespan. In humans, evidence is accumulating for an additive multilocus model, i.e. multiple genes with modest effect, working independently and as a network [1]. Because of the suggested additive effects of different genetic

${ }^{1}$ Italian National Research Center on Aging (I. N. R. C. A.), Contrada Muoio Piccolo, 87100, Cosenza, Italy variants predisposing to longevity, the combined approach of linkage analysis in affected sib pairs (ASP) in candidate regions for high frequent variants and Genome Wide Association for less frequent polymorphisms [1] is considered promising for the identification of the genetic component of human longevity. Among the genes for which association has been demonstrated with human longevity, there are Apolipoprotein genes (APOE, APOB, ACE, APOC3), sirtuin genes (SIRT1 and SIRT3), genes belonging to the anti-oxidant (SOD1, SOD2, PON1, FOXO3A) and inflammatory pathways (Klotho, CETP, IL6). A relevant role seems to be represented also by the inherited and somatic variability of the mitochondrial genome.

\section{Author details}

${ }^{1}$ Italian National Research Center on Aging (I. N. R. C. A.), Contrada Muoio Piccolo, 87100, Cosenza, Italy. ${ }^{2}$ Department Cell Biology, University of Calabria, 87036, Rende (Cs), Italy.

Published: 19 May 2010

Reference

1. Christensen $\mathrm{K}$, Johnson TE, Vaupel JW: The quest for genetic determinants of human longevity: challenges and insights. Nat Rev Genet 2006, 7:436-48.

doi:10.1186/1471-2318-10-S1-L39

Cite this article as: Mari and Dato: Genetics of longevity. BMC Geriatrics 2010 10(Suppl 1):L39.

Submit your next manuscript to BioMed Central and take full advantage of:

- Convenient online submission

- Thorough peer review

- No space constraints or color figure charges

- Immediate publication on acceptance

- Inclusion in PubMed, CAS, Scopus and Google Scholar

- Research which is freely available for redistribution

Submit your manuscript at www.biomedcentral.com/submit
C Biomed Central 